\title{
Fish community structure and depth-related trends on the continental slope of the Balearic Islands (Algerian basin, western Mediterranean)
}

\author{
Joan Moranta $^{1, *}$, Constantí Stefanescu ${ }^{2}$, Enric Massutí ${ }^{3}$, Beatriz Morales-Nin $^{1}$, \\ Domingo Lloris ${ }^{4}$
}

\author{
${ }^{1}$ CSIC-UIB, Institut Mediterrani d'Estudis Avançats, Campus Universitarí, E-07071 Palma de Mallorca, Spain \\ ${ }^{2}$ Can Liro, E-08458 Sant Pere de Vilamajor, Spain \\ ${ }^{3}$ IEO, Centre Oceanogràfic de les Balears, Moll de Ponent s/n, PO Box 291, E-07080 Palma de Mallorca, Spain \\ ${ }^{4}$ CSIC, Institut de Ciències del Mar, Passeig Joan de Borbó s/n, E-08039 Barcelona, Spain
}

\begin{abstract}
A total of 13026 fishes belonging to 82 species and 43 families were collected in a continuous transect between depths of 200 and $1800 \mathrm{~m}$ south of the Balearic Islands (Algerian basin, western Mediterranean). The analysis of 32 bottom trawls showed the existence of 4 groups associated with the upper slope (groups 1 and 2, from 200 to 400 and 400 to $800 \mathrm{~m}$, respectively), middle slope (group 3 . from 800 to $1400 \mathrm{~m}$ ) and lower slope (group 4, below a depth of $1400 \mathrm{~m}$ ). The differences in the mean values of the ecological parameters species nchness, abundance, biomass and mean fish weight were also indicative of distinctive characteristics between these fish assemblages. Species richness decreased significantly with depth. The highest values of diversity corresponded to the samples from group 2. Biomass did not show any specific trend throughout the whole bathymetric range. Mean fish weight show 2 different trends along the continental slope: a bigger-deeper phenomenon at the upper 1000 to $1200 \mathrm{~m}$ depth, and a smaller-deeper phenomenon below this depth. Our results are compared with those obtained in the north Atlantic basin and in the western Mediterranean (Balearic basin), and the main factors affecting these deep-sea fish assemblages are discussed.
\end{abstract}

KEY WORDS: Deep sea - Demersal ichthyofauna - Bathymetric distribution - Western Mediterranean

\section{INTRODUCTION}

The structure of faunal assemblages on the continental slope in different geographic areas is largely determined by spatial differences in environmental and oceanographic local conditions and in particular by depth, bottom type and characteristics of water masses (e.g. Haedrich \& Krefft 1978, Haedrich et al. 1980, Carney et al. 1983, Haedrich \& Merrett 1990. Hecker 1990, Bianchi 1992, Koslow 1993, Smale et al. 1993, Sardà et al. 1994).

Biological factors such as resource availability, predator-prey relationships and interspecific competition may also play a fundamental role in the local zonation

-E-mail: ieajmmps.uib.es pattern (e.g. Vinogradov \& Tseitlin 1983, Sulak 1984, Anderson et al. 1985, Macpherson \& Roel 1987, Merrett 1987, Mahaut et al. 1990, Gordon et al. 1995).

The distribution patterns and community structure of the fish community along the continental shelf and slope of the western Mediterranean are well known. However, most related studies are limited to data collected by fishing vessels and on oceanographic surveys at depths of less than 700 to $800 \mathrm{~m}$ (e.g. Maurin 1962, 1965, 1968, Matallanas 1979, Allué 1985, Gil de Sola 1994, Massutí et al. 1996b). Below these depths, the only available data are those provided by Stefanescu et al. $(1992 \mathrm{a}, 1993,1994)$ between 1000 and $2250 \mathrm{~m}$ in the Catalan Sea (Balearic basin), an area of the northwestern Mediterranean bounded by the Iberian peninsula coast to the north and west, and the Balearic Islands to the south. 
In this paper we describe the faunal composition, bathymetric distribution and zonation of the demersal fish fauna along a continuous transect between depths of 200 and $1800 \mathrm{~m}$, south of the Balearic Islands (Algerian basin, western Mediterranean). This study is one of a series in order to compare the demersal fish assemblages of 2 areas (the northern and southern Balearic Islands, in the Balearic and Algerian basins, respectively, see Fig. 1) with different bottom topography and hydrographic conditions (e.g. Canals et al. 1982, EUROMODEL Group 1995). The main objective is to detect general trends in the distribution of the fish fauna in relation to environmental and biological variables.

\section{MATERIAL AND METHODS}

Study area. The Algerian basin, within the western Mediterranean, has maximum depths of around $2500 \mathrm{~m}$ and is connected with the Balearic basin by a series of sills that occur in the arc of the Balearic Islands: $800 \mathrm{~m}$ between Eivissa and the mainland, $600 \mathrm{~m}$ between Eivissa and Mallorca, and less than $100 \mathrm{~m}$ between Mallorca and Menorca (Fig. 1). This topography plays an important role in the general circulation and in the transport of the water masses between these areas.

Although the western Mediterranean is characterised by a degree of high environmental stability in both temperature and salinity below a depth of $200 \mathrm{~m}$ (Hopkins 1985), distinct oceanographic conditions with biological implications have been described in the area. The zone south of the Balearic Islands (our study area, Fig. 1) is influenced by the dynamics of the Algerian basin, which acts as a reservoir for water of Atlantic origin (Millot 1985). Moreover, in the Balearic basin. (north of the Balearic Islands) the circulation of the water masses is similar to a large cyclonic gyre, controlled by 2 permanent front systems following slope bathymetric contours: cold Mediterranean Waters (MW) flow from the north along the continental shelf-break and warm Modified Atlantic Water (MAW) enter the Balearic basin from the south following the Balearic slope (Millot 1987, Font et al. 1988, Pinot et al. 1995). These frontal boundary regions are particularly relevant in the general oligotrophic context of the Mediterranean Sea, since they increase the biomass (Lhorenz et al. 1988) and further enrich already biologically active locations in the western Mediterranean.

Trawl data. All the material included in the present paper was collected south of Eivissa and the Formentera Islands during the QUIMERA-I cruise carried out on board the RV 'Garcia del Cid' in October 1996 (Fig. 1). The sampling gear was an OTMS-27.5 benthic trawl (Spanish patent no. 9200614, Institut de Ciencies del Mar-CSIC), which consists of a semiballoon otter trawl with square panels and wings and a $25 \mathrm{~m}$ headline. The gear is towed by a single warp attached to 2 wires on a crowfoot, which is in turn connected to two $450 \mathrm{~kg}$ iron otter boards (Sardà et al. 1998). Towing speed was 2.7 knots for all trawls. The arrival and departure of the net on the bottom in addition to the horizontal and vertical openings $14 \mathrm{~m}$ and 1.8 to $2 \mathrm{~m}$, respectively) were measured using the SCANMAR system (cod end mesh size was $12 \mathrm{~mm}$ ). The position at the start and the end of each trawl was recorded using GPS (Global Positioning System)

A total of 32 trawls were taken between depths of 200 and $1800 \mathrm{~m}, 2$ for each of sixteen $100 \mathrm{~m}$ depth

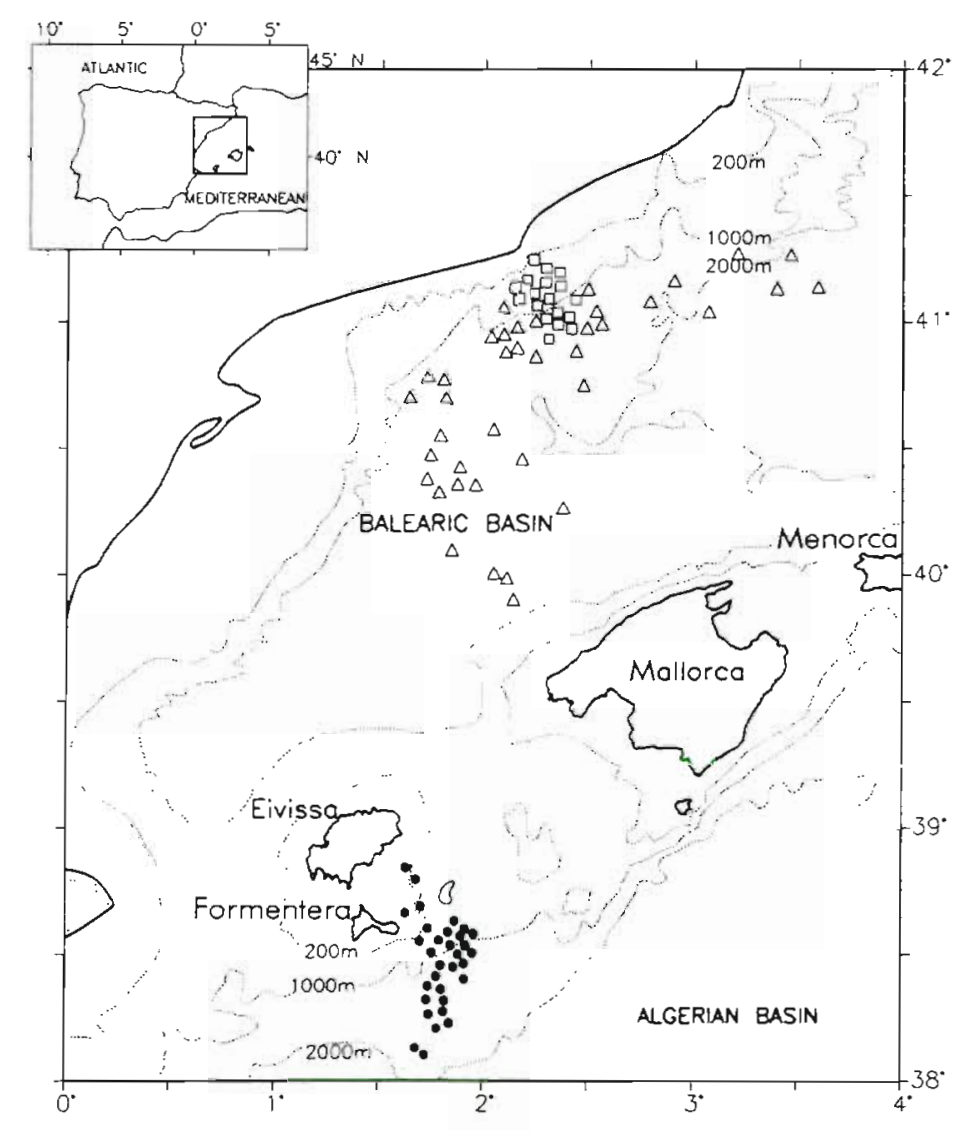

Fig. 1. General Iocation of the study site in the western Mediterranean showing the sampling stations on the contunental slope of the Algerian basin and the hatils from the Balearic basin used for comparative purposes. The horizontal distance separating the Algerian basin sampling sites from the ones in the Balearic basin is around 100 nautical miles. (-) Samples obtained with an OTMS-27.5 (present study); ( 4 ) samples obtained with an ()TSB-14 (from Stefanescu et al. 1993); (口) samples obtained with an OTMS-27.5 (from Stefanescu et al. 1994) 
intervals. Trawl duration was normally from 30 to 60 min but was standardised to $1 \mathrm{~h}$ for subsequent numerical processing. The catch values (abundance and biomass) were standardised to $1000 \mathrm{~m}^{2}$ in accordance with the methodology most commonly employed in studies of deep-sea fish assemblages (Stefanescu et al. 1994 and references cited therein). Those species regarded as markedly mesopelagic and bathypelagic in behaviour were disregarded in the quantitative calculations since they might have been captured at some distance from the bottom (see Table 1)

Data analysis. The quantitative species composition for each of eight $200 \mathrm{~m}$ intervals was analysed. In each interval the dominant species in terms of both abundance and biomass (expressed in percentages) were determined. To detect zonation patterns, cluster analysis was applied to the species abundance matrix. Species recorded only in a single sample were omitted from this analysis, since it was felt that the only effect of including such species would be to produce noise in the analysis. When the cluster analysis was carried out with the complete data set, excluding mesopelagic but not occasional species, a similar pattern arose. However, we found it difficult to identify some of the groups and therefore the species appearing in a single sample were not considered in the final cluster analysis. The Percentage of Similarity independent (PSi) was chosen as the similarity coefficient (Kohn \& Riggs 1982) and Complete Linkage Clustering and Unweighted Pair-Group Mean Analysis (UPGMA) were utilised as the clustering algorithm (Sneath \& Sokal 1973), since both are commonly used in deep-sea fish community studies. The application of other similarity coefficients for comparative purposes produced similar groupings.

The ecological parameters abundance, biomass, mean fish weight, species richness (S), mean species richness, Shannon-Wiener diversity index (Shannon \& Weaver 1949) and evenness (Pielou 1969) were determined in each group resulting from the cluster analysis.

The geometric mean was preferred to the arithmetic mean in comparisons of abundance, biomass and mean fish weight between groups of cluster analysis, in order to minimise the negative effects caused by extreme values. Before using parametric tests (1-way analysis of variance), the assumptions of normality and homoscedasticity were tested by the Kolmogorov-Smirnov and Bartlett-Box tests, respectively. When these assumptions were not met, non-parametric tests (KruskalWallis and Mann-Whitney) were used. Regression analyses were used to determine how species richness, abundance, biomass and mean fish weight changed with the water depth.
The Shannon-Wiener diversity index $\left(H^{\prime}\right)$ was determined according to the information function:

$$
H^{\prime}=\sum p i \ln p i
$$

where $p i$ is the fraction of species $i$ in the sample. Pairwise comparisons using the t-test (Hutchenson 1970) were used to detect significant difference in $H^{\prime}$ between groups.

The evenness index $\left(J^{\prime}\right)$ was calculated according to:

$$
J^{\prime}=\frac{H^{\prime}}{H_{\max }}
$$

where maximal diversity $H_{\text {rnax }}=\log S$, with $S$ being the species richness.

The bathymetric distribution of demersal species captured on more than one occasion was calculated in a quantitative manner using the 'centre of gravity' (COG) (Daget 1976) and 'habitat width' (HW) (Pielou 1969) analyses. The COG model allows one to calculate and locate with precision the centre of species distributions by means of a descriptor (in this case depth). The HW model gives a measure of heterogeneity of the species distribution.

Both values were determined as follows:

$$
\mathrm{COG}=\left(x_{1}+2 x_{2}+3 x_{3}+4 x_{4}+\ldots+n x_{n}\right) / \sum x_{i}
$$

where $x_{1}$ represents the calculated mean abundance values of the species $x$ present in the stratum $i$ (before analysis the sampled depth was divided into 8 strata of $200 \mathrm{~m}$ ).

$$
\mathrm{HW}=\mathrm{e}^{H^{\prime}}
$$

where e is the natural log and $H^{\prime}$ the Shannon-Wiener function. The same models were applied by Stefanescu et al. (1992a) in a previous study of bathymetric distributions of deep-sea fishes.

To test the reliability of species richness estimates $\left(S_{t}\right)$, cumulative species richness curves were constructed. These curves show an increase in species with increasing sampling intensity (cf. Blondel 1979). At a certain sample number $(n)$ an asymptotic value is reached when the 2 values $S_{n}$ and $S_{n-1}$ are equal. The curve is obtained by calculating the mean value for each point $S_{x}(x=1,2, \ldots, n)$ for all possible calculations of the $n$ samples, taken as 1 in 1 (point $S_{1}$ ), 2 in 2 (point $\left.S_{2}\right), \ldots, n$ in $n$ (point $S_{n}$ ).

\section{RESULTS}

A total of 13026 fishes belonging to 82 species and 43 families were collected, resulting in a biomass of $637.2 \mathrm{~kg}$ of fish from 32 trawls (Table 1)

The faunistic composition of abundance, biomass and frequency of occurrence, by species, for each $200 \mathrm{~m}$ depth interval is given in Table 2. In all aspects Gadiculus argenteus and Helicolenus dactylopterus 
Table 1. Specles caught of the southern Balearic Islands (western Mediterranean) between depths of 200 and $1800 \mathrm{~m}$. A. abundance in number of

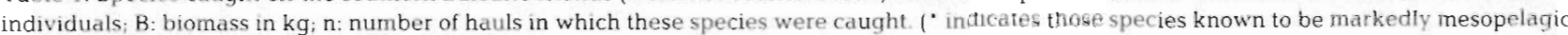
and bathypelagic in behaviour which were distegarded from the analysis)

\begin{tabular}{|c|c|c|c|c|}
\hline Famıly & Species & A & $\mathrm{B}$ & $n$ \\
\hline \multirow[t]{2}{*}{ Scyliorhinidae } & Galeus melastomus Rafinesque, 1810 & 468 & 60.48 & 23 \\
\hline & Scyliorhinus canicula (Linnaeus, 1758) & 231 & 10.40 & 7 \\
\hline \multirow[t]{5}{*}{ Squalidae } & Centrophorus uyato (Rafinesque, 1809) & 1 & 4.00 & 1 \\
\hline & Centroscynnnus coelolepis Bocage \& Capello, 1864 & 29 & 16.50 & 9 \\
\hline & Dalatias licha (Bonnaterre, 1788) & 5 & 9.01 & 4 \\
\hline & Etmopterus spinax (Linnaeus, 1758) & 43 & 10.33 & 15 \\
\hline & Squalus blainvillej (Risso, 1826 ) & 24 & 2.40 & 1 \\
\hline \multirow[t]{3}{*}{ Rajidae } & Raja naevus Müller \& Henle, 1841 & 3 & 0.93 & 1 \\
\hline & Raja asterias Delaroche, 1809 & 2 & 090 & 1 \\
\hline & Raja polystigma Regan, 1923 & 1 & 0.22 & 1 \\
\hline Alepocephalidae & Alepocephalus rostratus Risso, 1820 & 723 & 200.21 & 18 \\
\hline \multirow[t]{2}{*}{ Gonostomatidae } & Cyclothone braueri Jespersen \& Tăning, $1926^{\circ}$. & 25 & 0.02 & 7 \\
\hline & Cyclothone pygmaea Jespersen \& Tâning, $1926^{\circ}$ & 14 & 0.01 & 5 \\
\hline \multirow[t]{2}{*}{ Sternoptychidae } & Argyropelecus hemigymnus Cocco, $1829^{\circ}$ & 44 & 0.04 & 23 \\
\hline & Maurolicus muelleri (Gmelin, 1.788)" & 2 & 0.00 & 2 \\
\hline Chauliodontidae & Chauliodus sloani Schneider, 1801 & 13 & 0.49 & 10 \\
\hline Stomiidae & Stomias boa (Risso, 1810$)^{\circ}$ & 17 & 0.12 & 9 \\
\hline Argentinidae & Argentina sphyraena Linnaeus, $1758^{\circ}$ & 255 & 1.14 & 2 \\
\hline & Glossanodon leioglossus (Valenciennes, 1848)" & 1.42 & 11.41 & 3 \\
\hline Chlorophthalmidae & Chlorophthalmus agassizii Bonaparte, 1840 & 7 & 0.04 & 5 \\
\hline & Bathypterois mediterraneus Bauchot, 1962 & 410 & 2.81 & 15 \\
\hline Myctophidae & Benthosema glaciale (Reinhardt, 1837$)^{*}$ & 19 & 0.02 & 7 \\
\hline & Lampanyctus crocodilus (Risso, 1810$)^{\circ}$ & 308 & 2.75 & 24 \\
\hline & Myctophum punctatum Rafinesque, $1810^{\circ}$ & 5 & 0.00 & 2 \\
\hline & Notoscopelus elongatus (Costa, 1844)" & 1 & 0.00 & 1 \\
\hline Paralepididae & Notolepis rissoi (Boneparte, 1840)' & 6 & 0.01 & 6 \\
\hline Nemichthyidae & Nemichthys scolopaceus Richardson, $1848^{\circ}$ & 1 & 0.01 & 1 \\
\hline Nettastomatidae & Nettastoma melanurum Rafinesque, 1810 & 30 & 2.95 & 13 \\
\hline Congridae & Conger conger (Linndèus, 1758) & 3 & 5.64 & 3 \\
\hline Synaphobranchidae & Dysonma brevirostre (Facciola, 1887) & 1 & 0.04 & 1. \\
\hline Notacanthidae & Notacanthus bonapartei Risso, 1840 & 14 & 0.51 & 9 \\
\hline & Polyacanthonotus rissoanus (Filippi \& Verany. 1859) & 17 & 0.21 & 8 \\
\hline Macroramphosidae & Macroramphosus scolopax (Linnaeus, 1758) & 31 & 0.20 & 3 \\
\hline Macrouridae & Chalinura mediterranea Giglioli, 1893 & 142 & 1.06 & 10 \\
\hline & Caelorhynchus caelorhynchus (Risso, 1810) & 239 & 3.92 & i \\
\hline & Caelorhynchus labiatus (Koehler, 1896) & 122 & 2.34 & 11 \\
\hline & Coryphaenoides guentheri (Vaillant, 1888) & 9 & 0.08 & 3 \\
\hline & Hymenocephalus italicus Giglioli, 1884 & 119 & 1.12 & 11 \\
\hline & Nezumia aequalis (Gunther, 1878) & 484 & 14.86 & 18 \\
\hline & Trachyrincus trachyrincus (Giornd, 1809) & 15 & 3.24 & 3 \\
\hline Merluccidae & Merluccius merluccius (Linnaeus, 1758) & 340 & 9.80 & 10 \\
\hline Gadidae & Gadiculus argenteus Guichenot, 1850 & 4761 & 16.36 & 9 \\
\hline & Micromesistius poutassou (Risso, 1926) & 36 & 2.90 & 8 \\
\hline & Trisopterus minutus capelanus (Lacepede, 1800) & 42 & 0.41 & 2 \\
\hline & Antonogadus megalokynodon (Kolombatovic, 1894) & 29 & 0.08 & 11 \\
\hline & Molva dipterygia macrophtalma (Pennant, 1874) & 24 & 0.95 & 6 \\
\hline & Phycis blennoides (Brünnich, 1768) & 1100 & 41.10 & 19 \\
\hline Moridae & Laemonema sp. & 1 & 0.01 & 1 \\
\hline & Lepidion guentheri (Giglioli, 1880) & 5 & 2.09 & 3 \\
\hline & Lepidion lepidion (Risso, 1810) & 53 & 5.64 & 13 \\
\hline & Mora moro (Risso, 1810) & 242 & 131.12 & 12 \\
\hline Regalecidae & Regalecus glesne Ascanius, $1772^{\circ}$ & 1 & 0.00 & 1 \\
\hline Zeidae & Zeus faber Linnaeus, 1758 & 1 & 0.15 & 1 \\
\hline Caproidae & Capros aper (Linnaeus, 1758)" & 290 & 1.23 & 5 \\
\hline Apogonidae & Epigonus denticulatus Diuezeide, 1950 & 21 & 0.09 & 6 \\
\hline & Epigonus telescopus (Risso, 1810) & 9 & 6.50 & 2 \\
\hline Carangidae & Trachurus picturatus (Bowdich, 1825) & 2 & 0.39 & 1 \\
\hline & Trachurus trachurus (Linnaeus, 1758) & 44 & 4.00 & 1 \\
\hline Mulindae: & Mullus surmuletus Linnaeus, 1758 & 1 & 0.28 & 1 \\
\hline Sparidae & Boops boops (Limaeus, 1758)" & 8 & 0.95 & 3 \\
\hline Trachichthyidae & Hoplostethus mediterraneus Cuvier, 1829 & 64 & 2.61 & 9 \\
\hline Trichiuridae & Lepidopus caudatus (Euphrasen, 1788) & 52 & 3.05 & 10 \\
\hline Gobiidae & Lesueurigoblus friesii (Malm, 1874) & 2 & 0.00 & 1 \\
\hline & Pomatoschistus minutus (Pallas, 1770 & 1 & 0.00 & 1 \\
\hline Callionymidae & Callionymus maculatus Rafinesque-Schmaltz, 1810 & 7 & 0.01 & 2 \\
\hline & Synchiropus phaeton (Gunther, 1861) & 118 & 1.02 & 8 \\
\hline Bythitidae & Cataetyx alleni (Byrne, 1906) & 6 & 0.05 & 5 \\
\hline & Cataetyx laticeps Koefoed, 1927 & 1 & 0.64 & 1 \\
\hline Centrolophidae & Centrolophus niger (Gmelin, 1788)' & 1 & 3.00 & 1 \\
\hline Scorpaenidae & Helicolenus dactylopterus (Delaroche, 1809) & 1252 & 19.07 & 9 \\
\hline & Scorpaend elongata Cadenat, 1943 & 3 & 0.91 & 3 \\
\hline Triglidae & Aspitrigla cuculus (Linnaeus, 1758 ) & 1 & 0.07 & 1 \\
\hline & Lepidotrigla cavillone (Lacépède, 1801 个 & 1 & 0.01 & 1 \\
\hline & Trigla lyra Linnaeus, 1758 & 20 & 0.29 & 6 \\
\hline Peristeidad & Penistedion cataphractum Linnaeus, 1758 & 186 & 5.36 & 5 \\
\hline Liparidae & Paraliparis leptochirus (Tortonese, 1960). & 8 & 0.01 & 7 \\
\hline Scophthalmidere & Lepidorhombus boscil (Risso, 1810) & 38 & 2.19 & 7 \\
\hline Bothidae & Arnoglossus laterna (Walbaum, 1792) & 29 & 0.14 & 2 \\
\hline & Amoglossus rueppelli (Cocco, 1844) & 23 & 0.12 & 2 \\
\hline Cynoglossidae & Symphurus ligulatus (Cocco, 1844) & 90 & 0.21 & 9 \\
\hline & Symphurus nigrescens Rafinesque, 1810 & 86 & 038 & 10 \\
\hline Lophitdae & Lophius budegassa Spinola, 1807 & 2 & 042 & 2 \\
\hline & & 13026 & 637.2 & \\
\hline
\end{tabular}


Table 2. Top ranking species at each $200 \mathrm{~m}$ depth interval. Abundance and biomass are expressed as a percentage of the total catch for each bathymetric range and frequency of occurrence $(f)$ as the number of samples in which the species was caught in relation to the number of samples taken at each depth stratum. Only those species represented by more than $5 \%$ of the total catch are listed

\begin{tabular}{|c|c|c|c|c|c|}
\hline Abundance & $\%$ & $f$ & Biomass & $\%$ & $f$ \\
\hline \multicolumn{6}{|l|}{$200-400 \mathrm{~m}$} \\
\hline Gadiculus argenteus & 60.85 & 100 & Helicolenus dactylopterus & 27.62 & 100 \\
\hline Helicolenus dactylopterus & 17.18 & 100 & Gadiculus argenteus & 21.19 & 100 \\
\hline \multirow[t]{4}{*}{ Phycis blennoides } & 5.46 & 100 & Phycis blennoides & 12.61 & 100 \\
\hline & & & Scyliorhinus canicula & 1132 & 100 \\
\hline & & & Peristedion cataphractum & 7.87 & 100 \\
\hline & & & Merluccius merluccius & 5.34 & 100 \\
\hline \multicolumn{6}{|l|}{$400-600 \mathrm{~m}$} \\
\hline Phycis blennoides & 39.01 & 100 & Phycis blennoides & 32.06 & 100 \\
\hline Gadiculus argenteus & 18.59 & 80 & Galeus melastomus & 20.04 & 100 \\
\hline Galeus melastomus & 16.88 & 100 & Merluccius merluccius & 7.92 & 80 \\
\hline Caelorhynchus caelorhynchus & 5.49 & 60 & Caelorhynchus caelorhynchus & 5.99 & 60 \\
\hline \multicolumn{6}{|l|}{$600-800 \mathrm{~m}$} \\
\hline Nezumia aequalis & 23.02 & 100 & Galeus melastomus & 35.07 & 100 \\
\hline Symphurus ligulatus & 17.46 & 100 & Phycis blennoides & 21.80 & 100 \\
\hline Phycis blennoides & 16.93 & 100 & Nezumia dequalis & 10.67 & 100 \\
\hline Hymenocephalus italicus & 12.96 & 100 & Hoplostethus mediterraneus & 8.52 & 100 \\
\hline Hoplostethus mediterraneus & 8.20 & 100 & & & \\
\hline Galeus melastomus & 7.94 & 100 & & & \\
\hline \multicolumn{6}{|l|}{$800-1000 \mathrm{ml}$} \\
\hline Nezumia aequalis & 29.33 & 100 & Mora moro & 31.03 & 100 \\
\hline Phycis blennoides & 16.49 & 100 & Galeus melastomus & 15.77 & 100 \\
\hline Mora moro & 12.45 & 100 & Phycis blennoides & 12.26 & 100 \\
\hline Alepocephalus rostratus & 11.04 & 50 & Alepocephalus rostratus & 8.10 & 50 \\
\hline Galeus melastomus & 7.35 & 100 & Dalatias licha & 6.90 & 50 \\
\hline Hymenocephalus itahcus & 5.15 & 100 & & & \\
\hline \multicolumn{6}{|l|}{$1000-1200 \mathrm{~m}$} \\
\hline Alepocephalus rostratus & 35.02 & 100 & Mora moro & 51.89 & 100 \\
\hline Nezumia aequalis & 27.41 & 100 & Alepocephalus rostratus & 29.56 & 100 \\
\hline Mora moro & 22.49 & 100 & Galeus melastomus & 8.27 & 100 \\
\hline Galeus melastomus & 5.39 & 100 & & & \\
\hline \multicolumn{6}{|l|}{$1200-1400 \mathrm{~m}$} \\
\hline Alepocephalus rostratus & 51.92 & 100 & Alepocephalus rostratus & 69.88 & 100 \\
\hline Nezumia dequalis & 15.65 & 100 & Mora moro & 16.08 & 100 \\
\hline Caelorhynchus labiatus & 9.74 & 100 & Galeus melastomus & 8.20 & 66.67 \\
\hline Mora moro & 6.71 & 100 & & & \\
\hline Bathypterois mediterraneus & 5.75 & 100 & & & \\
\hline Galeus melastomus & 5.11 & 66.67 & & & \\
\hline \multicolumn{6}{|l|}{$1400-1600 \mathrm{~m}$} \\
\hline Bathypterois mediterraneus & 40.13 & 100 & Alepocephalus rostratus & 82.67 & 100 \\
\hline Alepocephalus rostratus & 29.33 & 100 & Lepidion lepidion & 6.25 & 100 \\
\hline Caelorhynchus labiatus & 11.47 & 100 & Centroscymnus coelolepis & 6.15 & 75 \\
\hline Chalinura mediterranea & 7.50 & 100 & & & \\
\hline Lepidion lepidion & 5.40 & 100 & & & \\
\hline \multicolumn{6}{|l|}{$1600-1800 \mathrm{~m}$} \\
\hline Bathypterois mediterraneus & 45.11 & 100 & Alepocephalus rostratus & 62.32 & 100 \\
\hline Chalinura mediterranea & 23.56 & 100 & Centroscymnus coelolepis & 17.89 & 100 \\
\hline Alepocephalus rostratus & 14.35 & 100 & & & \\
\hline Caelorhynchus labiatus & 5.78 & 100 & & & \\
\hline
\end{tabular}

were among the dominant species between depths of 200 and $400 \mathrm{~m}$, as were Phycis blennoides and Galeus melastomus in the bathymetric range shallower than $1000 \mathrm{~m}$. At intermediate depths, between 600 and $1400 \mathrm{~m}$, Nezumia aequalis and Mora moro were among the dominant species, while Alepocephalus rostratus was a co-dominant between 1000 and $1800 \mathrm{~m}$, and
Bathypterois mediterraneus dominated in abundance at depths greater than $1400 \mathrm{~m}$.

The bathymetric distributions, established using the COG and HW values, are shown in Fig. 2. From a total of 46 demersal species analysed, 34 were restricted to the depth interval surveyed. There were 4 different species groups: (a) species limited to the 200 to $800 \mathrm{~m}$ 


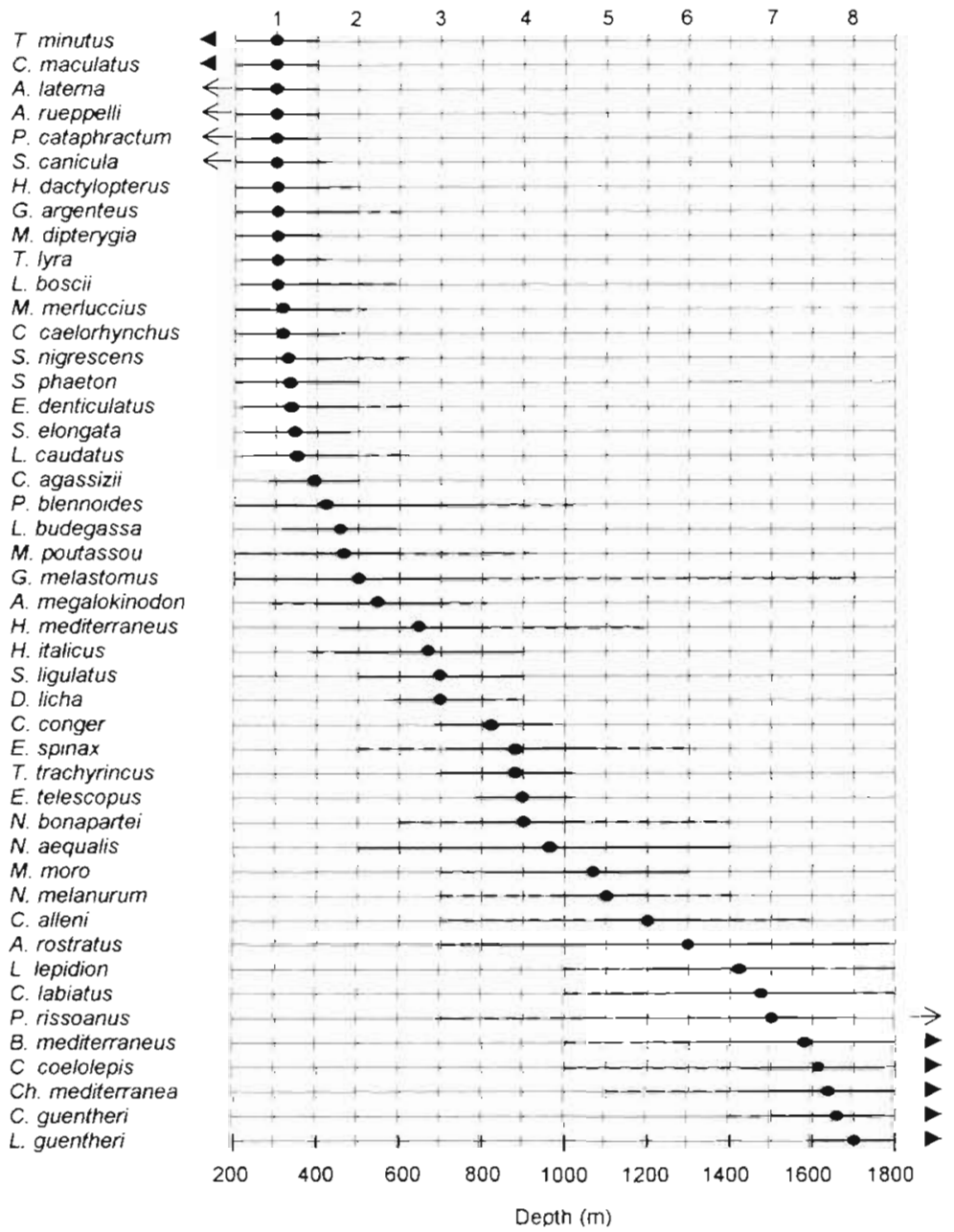

Fig. 2. Bathymetric distribution of demersal species sampled on more than 1 occasion. Black circles represent the centre of gravity (COG), black lines correspond to the habitat width (HW). Black arrowheads indicate a displacement in real terms of the COG beyond the depth range sampled according to other studies conducted in adjacent areas (Stefanescu et al. 1993, 1994, Massutí et al. 1996b). Thin arrows indicate a small displacement in real terms of the COG, but included in the depth range considered. Discontinuous lines indicate the bathimetric range over which given species were caught. Numbers 1 to 8 on the top axis correspond to the 8 sectors in which the sampled depth interval (200 to 1800) was divided. Full species names given in Table 1

depth interval (e.g. Helicolenus dactylopterus, Gadiculus argenteus, Lepidorhombus boscii, Merluccius merluccius and Caelorhynchus caelorhynchus), (b) species with a wide bathymetric distribution (Phycis blennoides, Galeus melastomus, Nezumia aequalis and Alepocephalus rostratus). (c) species present at intermediate depth between 800 to $1400 \mathrm{~m}$ (Trachyrinchus trachyrinchus, Mora moro, Nettastoma melanurum. and Cataetyx alleni), and (d) species restricted to depths greater than $1400 \mathrm{~m}$ (Lepidion lepidion, Caelorhynchus labiatus, Bathypterois mediterraneus and Centroscymnus coelolepis).
The dendrogram of similarities for the trawls is shown in Fig. 3. The first cluster separates those samples taken at a depth of 200 to $800 \mathrm{~m}$ from the rest. Within this group an additional subdivision can be discerned, and a second cluster separates the hauls shallower than $400 \mathrm{~m}$ (group 1) and those from 400 to $800 \mathrm{~m}$ (group 2). The rest of the samples are arranged into 2 groups delimited by the $1400 \mathrm{~m}$ isobath: from 800 to $1400 \mathrm{~m}$ (group 3) and samples below a depth of $1400 \mathrm{~m}$ (group 4). The number of hauls in each group resulting from cluster analysis was adequate to describe the different assemblages, as shown by the cumulative species richness curves (Fig. 4).

The values of some ecological parameters in the different groups and the results of the statistical analysis are given in Table 3 . The relationships between some of these parameters and depth, calculated by regression analyses, are shown in Fig. 5.

Both species richness and mean species richness, were higher in groups 1 (200 to $400 \mathrm{~m}$ ) and 2 (400 to $800 \mathrm{~m}$ ), than in groups 3 (800 to $1400 \mathrm{~m}$ ) and $4(1400$ to $1800 \mathrm{~m})$. Nevertheless, although species richness decreased significantly with depth (Fig. 5a), no significant differences were found between groups 3 and 4 . The highest values of diversity corresponded to the samples from group 2 (Table 3). Group 1 showed the lowest evenness and the highest abundance values, as a consequence of the predominance of Gadiculus argenteus, which appeared in vast numbers in all samples between a depth of 200 to $400 \mathrm{~m}$ and represented $60.9 \%$ of the specimens caught. Despite high species richness (Fig. 5a), this resulted in an abnormally low value on the Shannon-Wiener index for group 1 (Table 3).

Abundance was correlated with depth but this trend was accentuated in the first $500 \mathrm{~m}$ depth interval (Fig. 5b). Biomass did not show any specific trend in the first $1100 \mathrm{~m}$ depth interval but decreased significantly from 1100 to $1800 \mathrm{~m}$. Moreover, careful analysis revealed the existence of a minimum and a maximum located around 500 and 1100 to $1200 \mathrm{~m}$, respectively (Fig. 5c). Mean fish weight showed 2 different trends within the studied range. A steady increase was observed from 200 to $1100 \mathrm{~m}$, while a converse trend was noted from $1100 \mathrm{~m}$ down to the maximum depth sampled (Fig. 5d). 


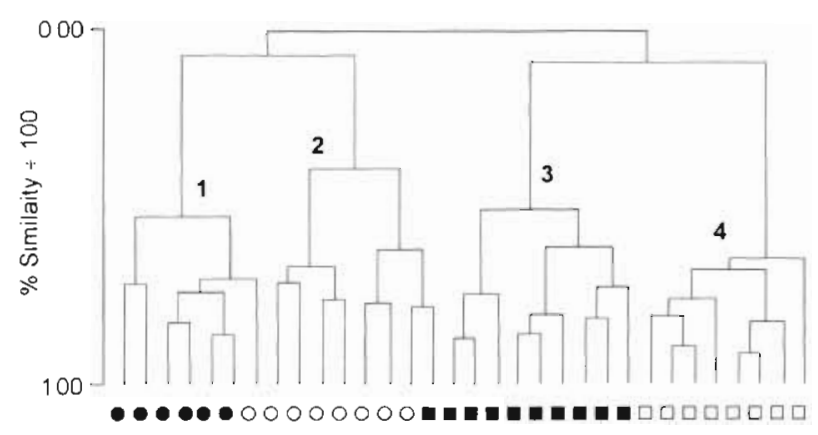

Fig. 3. Dendrogam of trawls during the QUIMERA I cruise showing 4 major clusters. (P) Stations at 200 to $400 \mathrm{~m}$; (O) stations at 400 to $800 \mathrm{~m}$ ( (a) stations at 800 to $1400 \mathrm{mi}$ (口) stations at 1400 to $1800 \mathrm{~m}$

\section{DISCUSSION}

The continental slope south of the Balearic Islands is characterised by 4 distinct fish assemblages. The zonation pattern obtained in our study can be associated with different bathymetric strata. Following the arbitrary separation proposed by Haedrich \& Merrett (1988) in North Atlantic waters, the 4 groups obtained in the cluster analysis (Fig. 3) can be associated with the upper slope (groups 1 and 2, between 200 and $800 \mathrm{~m}$ ), middle slope (group 3, from 800 to $1400 \mathrm{~m}$ ) and lower slope (below a depth of $1400 \mathrm{~m}$ ). These results agree with previous data available from the Catalan Sea (Balearic basin, Fig. 1). In this area, north of the Balearic Islands, different fish assemblages at depths of 350 to 650 and 1150 to $1300 \mathrm{~m}$ have been described by Stefanescu et al. (1994), and a boundary between

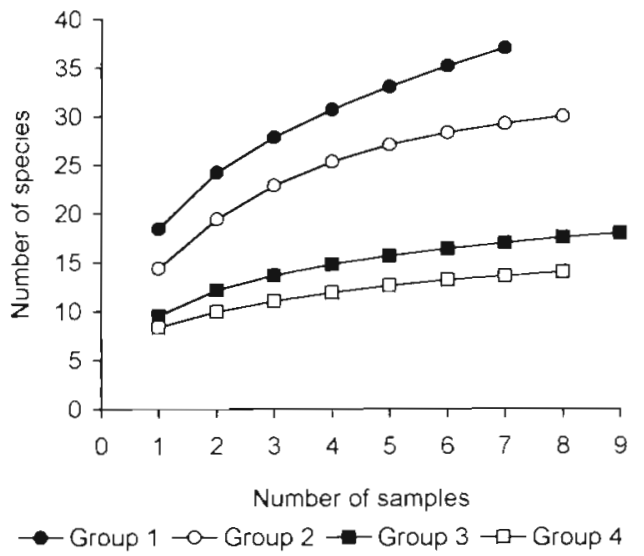

Fig. 4. Cumulative species richness curves in the 4 groups identified by cluster analysis (group 1: 200 to $400 \mathrm{~m}$; group 2:

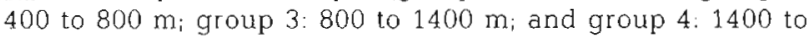
$1800 \mathrm{~m}$ )

the middle and lower slope was located around the $1400 \mathrm{~m}$ isobath (Stefanescu et al. 1993). The depth gradient, with its associated environmental and biological changes, is the main factor responsible for faunal change in demersal fish communities (e.g. Haedrich et al. 1975, Bianchi 1992, Stefanescu et al. 1993, Fujita et al. 1995, Gordon et al. 1995).

According to Hecker (1990), the changes in faunistic composition between different megafaunal assemblages are due to the substitution of the dominant and subdominant species, throughout the depth gradient, by a continuous faunistic turnover. This can be observed in our results (Table 2). For example, Phycis blennoides was caught at depths from 242 to $1022 \mathrm{~m}$, but was a dominant species from 400 to $600 \mathrm{~m}$ and sub-

Table 3. Ecological parameters for each group resulting from cluster analysis (see Fig. 3) and summary of statistical tests. Means are ranked sequentially, with the higher values on the left. Values underlined with the same line do nat show significant differences. $(\cdot p<0.05, \cdots p<001)$

\begin{tabular}{|c|c|c|c|c|c|c|}
\hline Group: & $\frac{1}{(200-400 \mathrm{~m})}$ & $\frac{2}{(400-800 \mathrm{~m})}$ & $\begin{array}{c}3 \\
(800-1200 \mathrm{~m})\end{array}$ & $\begin{array}{l}4 \\
(1200-1800 \mathrm{~m})\end{array}$ & Statistical test & Groups \\
\hline $\begin{array}{l}\text { Abundance } \\
\text { (fish } / 10^{3} \mathrm{~m}^{2} \text { ) }\end{array}$ & $\begin{array}{c}23.5 \\
(11.8-46.0)\end{array}$ & $\begin{array}{c}2.7 \\
(2.3-3.1)\end{array}$ & $\begin{array}{c}3.3 \\
(2.9-3.8)\end{array}$ & $\begin{array}{c}3.1 \\
(2.0-4.4)\end{array}$ & $\begin{array}{l}\text { Kruskal-Wallis } \\
\left(H_{4,8,8,7}=18.5^{\circ}\right)\end{array}$ & $\mathrm{G} 1>\mathrm{G} 3>\mathrm{G} 4>\mathrm{G} 2$ \\
\hline $\begin{array}{l}\text { Biomass } \\
\left(\mathrm{g} / 10^{3} \mathrm{~m}^{2}\right)\end{array}$ & $\begin{array}{c}346.2 \\
(231.8-517.0)\end{array}$ & $\begin{array}{c}164.7 \\
(59.3-453.9)\end{array}$ & $\begin{array}{c}764.1 \\
(684.4-861.6)\end{array}$ & $\begin{array}{c}297.9 \\
(147.4-606.9)\end{array}$ & $\begin{array}{l}\text { Kruskal-Wallis } \\
\left(H_{9,8,8,7}=12.9^{\circ}\right)\end{array}$ & $\mathrm{G} 3>\mathrm{G} 1>\mathrm{G} 4>\mathrm{G} 2$ \\
\hline $\begin{array}{l}\text { Mean fish } \\
\text { weight }(g)\end{array}$ & $\begin{array}{c}14.9 \\
(10.5-21.2)\end{array}$ & $\begin{array}{c}61.8 \\
(24.3-155.0)\end{array}$ & $\begin{array}{c}229.4 \\
(205.4-258.8)\end{array}$ & $\begin{array}{c}101.5 \\
(69.1-147.4)\end{array}$ & $\begin{array}{c}\text { Kruskal-Wallis } \\
\left(H_{9,8,8,7}=21.6^{*}\right)\end{array}$ & $\mathrm{G} 3>\mathrm{G} 4>\mathrm{G} 2>\mathrm{G} 1$ \\
\hline Species richness $(S)$ & 37 & 30 & 18 & 14 & & \\
\hline $\begin{array}{l}\text { Mean species } \\
\text { richness }\end{array}$ & $17.4 \pm 0.9$ & $14.4 \pm 0.5$ & $9.6 \pm 0.53$ & $8.38 \pm 0.38$ & $\begin{array}{c}\text { One-way } \\
\left(F_{(1), 3,28}=58.62 \cdots\right)\end{array}$ & $\mathrm{G} 1>\mathrm{G} 2>\mathrm{G} 3>\mathrm{G} 4$ \\
\hline Diversity $\left(H^{\prime}\right)$ & 1.78 & 2.36 & 1.76 & 1.64 & Student's $t$ & $\mathrm{G} 2>\mathrm{G} 1>\mathrm{G} 3>\mathrm{G} 4$ \\
\hline Evenness $\left(J^{\prime}\right)$ & 0.38 & 0.49 & 0.42 & 0.43 & & \\
\hline Mean depth $( \pm S D)$ & $339.3 \pm 66.1$ & $656.7 \pm 115.5$ & $1087 \pm 145.5$ & $1553.9 \pm 119.2$ & & \\
\hline Number of samples & 7 & 9 & 8 & 8 & & \\
\hline
\end{tabular}



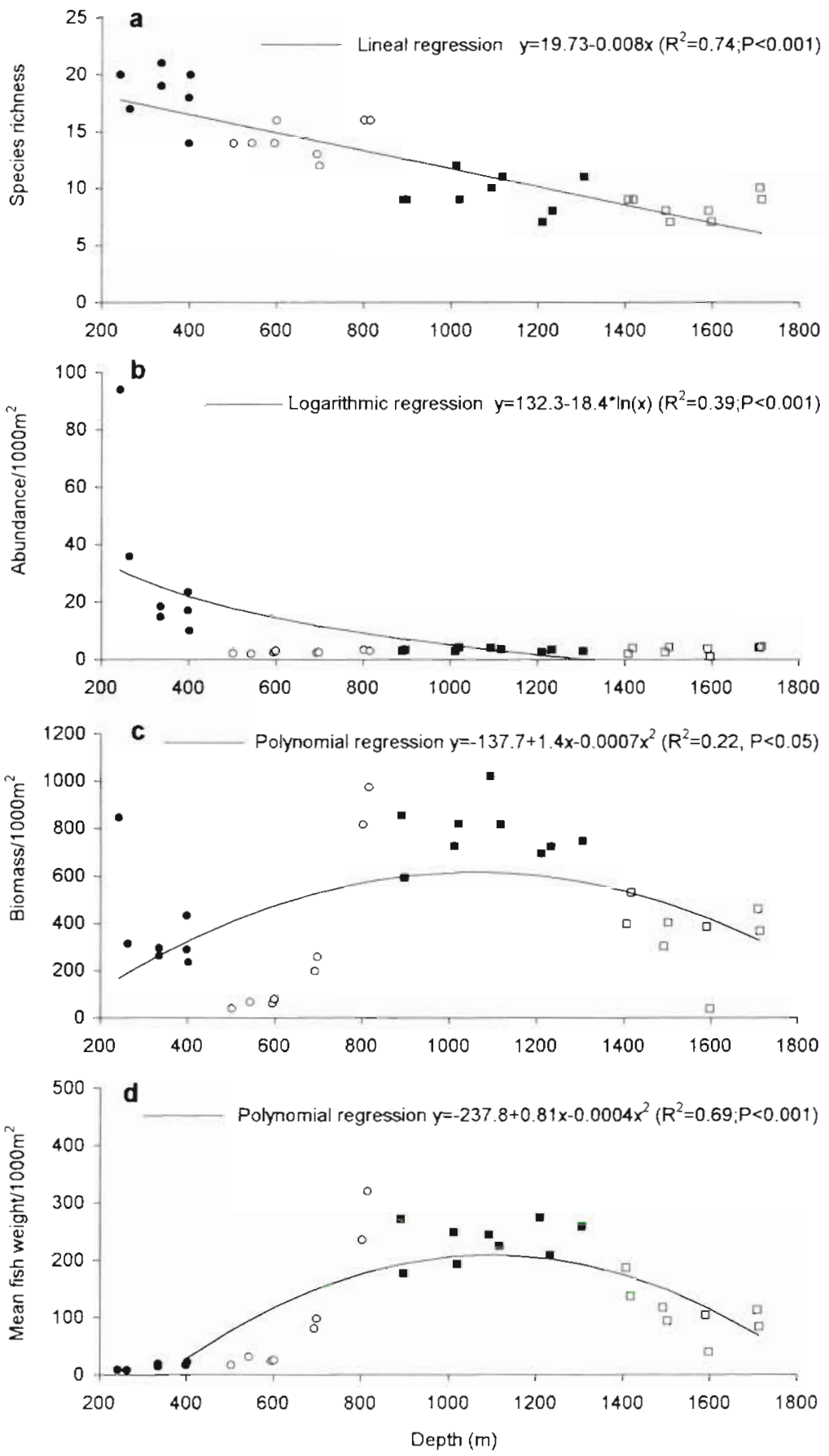

Fig. 5. Relationship between (a) species richness, (b) abundance, (c) biomass and (d) mean fish weight and depth, calculated by regression analyses. The symbols correspond with the different groups identified by cluster analysis. (-) Group 1, stations at 200 to $400 \mathrm{~m}_{\text {i }}$ (0) group 2, stations at 400 to $800 \mathrm{~m}$; (-) group 3, stations at 800 to $1400 \mathrm{~m}$; (a) group 4, stations at 1400 to $1800 \mathrm{~m}$

dominant in the other depth groups in which the species was present. In the same way, Alepocephalus rostratus appeared between $700 \mathrm{~m}$ and the maximum depth surveyed, but was dominant from 1000 to
$1600 \mathrm{~m}$ and subdominant at depths of 800 to 1000 and 1600 to $1800 \mathrm{~m}$. Bathypterois mediterraneus was caught in all the hauls below a depth of $1013 \mathrm{~m}$ but was only abundant at 1400 to 1800

On the other hand, other species such as Peristedion cataphractum, Scyliorhinus canicula, Trisopterus minutus capelanus, Arnoglossus rueppelli, A. laterna, Callionymus maculatus, Molva dipterygia macrophtalma and Trigla lyra showed a narrow bathymetric distribution within the depth range surveyed and appeared only between 200 and $400 \mathrm{~m}$ (Fig. 2). These species accounted for the 2 different assemblages obtained on the upper slope: groups 1 and 2 at 200 to 400 and 400 to $800 \mathrm{~m}$, respectively (Fig. 3).

The differences in the mean values of the ecological parameters analysed (Table 3, Fig. 5) are also indicative of distinctive differences which characterise the various fish assemblages found in this study. Species richness decreased progressively throughout the whole depth range surveyed (Figs. $4 \& 5$ a) and suggested a real faunistic impoverishment with depth. This trend has been reported from the upper slope down to about 2000 $m$ in Atlantic (e.g. Haedrich et al. 1980, Gordon \& Duncan 1985) and Pacific waters (Pearcy et al. 1982). A similar pattern was described by Stefanescu et al. (1993) in western Mediterranean waters deeper than $1000 \mathrm{~m}$.

The number of demersal fish species recorded in the western Mediterranean in a series of comparable studies has been 57,27 , and 16 for the upper, middle and lower slope, respectively (Stefanescu et al. 1992a, Massutí et al. 1996b, and the present study). A comparison of these numbers with those recorded by Haedrich \& Merrett (1988) in 4 regions around the north Atlantic Basin with a similar number of samples and bottom trawls (Bahamas, middle Atlantic Bight, Rockall Trough and Porcupine Seabight), reveals different trends along the entire range of the slope. Thus, in our study, the number of demersal species recorded on the upper slope represents an increase of 33.3 and $15.8 \%$ with respect to Rockall Trough and Porcupine Seabight (no data are available for the Bahamas and the middle Atlantic Bight). These differences may be explained 
by the effect of a narrow continental shelf in our surveyed area and the subsequent increase in the capture of species such as Peristedion cataphractum, Scyliorhinus canicula, Trisopterus minutus capelanus, Callionymus maculatus, Molva dipterygia macrophtalma, Raja naevus, R. asterias, Zeus faber, Trachurus picturatus, T. trachurus, Mullus surmuletus, Aspitrigla cuculus, Lepidotrigla cavillone, Trigla lyra, Arnoglossus rueppelli and A. laterna, which generally display a wide bathymetric distribution range throughout the continental shelf and the upper slope (Massutí et al. 1996b). Moreover, these differences may be influenced in part by the general latitudinal trend towards decrease in species richness with increasing latitude (Macpherson \& Duarte 1994, and references cited therein).

In contrast, the number of demersal species recorded in the middle and lower slope represents a decrease of 32.5 and $59.7 \%$ with respect to the values reported in the north Atlantic by Haedrich \& Merrett (1988). This fits well with the general assumption that the demersal fish fauna in the Mediterranean deep-sea is poorer than in the north Atlantic basin (Haedrich \& Merrett 1988, Stefanescu et al. 1992a). In this way, the Gibraltar sill, $280 \mathrm{~m}$ deep, has been regarded as the main physical barrier for the potential colonization of the Mediterranean from the rich deep-sea Atlantic fauna (Bouchet \& Taviani 1992). Therefore, those fish species with a distribution range starting below a depth of $300 \mathrm{~m}$ cannot colonize the Mediterranean unless they have pelagic larvae. Moreover, the hydrological nature of the Mediterranean bottom water (high temperature and high salinity) can act as another important barrier to the successful establishment of species with such a larval dispersal capacity (Bouchet \& Taviani 1992) This relative isolation may explain the evolution of endemic species such as Bathypterois mediterraneus and Lepidion lepidion, 2 main constituents of the deepsea Mediterranean fish fauna (Stefanescu et al. 1993, Morales-Nin et al. 1996). In addition, it is interesting to note that the differences in number of demersal species between the northern Atlantic and western Mediterranean are greater with increasing depth. The greatest impoverishment occurring on the lower slope may be related to the sharp reduction in available trophic resources below 1000 to $1200 \mathrm{~m}$, that is, below the depth range of greatest potential vertical and horizontal impingement of the epipelagic and mesopelagic fauna on the slope (Mauchline \& Gordon 1991, Stefanescu et al. 1993).

Fish abundance decreased significantly only on the upper slope, and remained constant below $500 \mathrm{~m}$ (Fig. 5b). An exponential decrease of abundance with depth has been reported by several authors in other areas (Grassle et al. 1975, Cohen \& Pawson 1977, Mer- rett \& Marshall 1981, Merrett \& Domanski 1985, Gordon 1986, Merrett et al. 1991). The stable tendency in the values between depths of 500 and $1800 \mathrm{~m}$ coincides with the previous results obtained in the Catalan Sea below $1000 \mathrm{~m}$ (Stefanescu et al. 1993) and are in accordance with those obtained in other oligotrophic areas of the Atlantic Ocean (Sulak 1984).

The maximum biomass values were abtained at around a depth of 1100 to $1200 \mathrm{~m}$ (Table 3, Fig 5c). This peak of biomass on the middle slope has been reported both in the Atlantic (Marshall \& Merrett 1977 , Gordon \& Duncan 1985, Gordon 1986) and in the western Mediterranean (Stefanescu et al. 1993). As abundance remained uniform below $800 \mathrm{~m}$ (Fig. 5b), high values of biomass on the middle slope must be due to an increase in fish size rather than an overall increase in number. Consequently, a bigger-deeper trend appeared on the upper and middle slopes. Middle and large-sized species (e.g. Mora moro, Alepocephalus rostratus, Galeus melastomus, Phycis blennoides and Nezumia aequalis) reach their highest abundance between 800 and $1200 \mathrm{~m}$ and replace smaller species that dominate at lesser depths (e.g. Gadiculus argenteus, Symphurus ligulatus and Hymenocephalus italicus), which accounts for the observed pattern. Moreover, at the species level a bigger-deeper phenomenon is also a characteristic feature of some dominant species of the upper and middle slope assemblages such as Symphurus ligulatus, $G$, argenteus, $N$. aequalis and P. blennoides (cf. Massutí et al. 1995, 1996a).

The decrease in biomass below $1100 \mathrm{~m}$, coupled with the uniformity in abundance values, results in a smaller-deeper trend from this depth (Fig. 5d). Largesized species become scarcer and are replaced by smaller ones such as Bathypterois mediterraneus, Lepidion lepidion, Caelorhynchus labiatus and Chalinura mediterranea. At the species level a larger-deeper trend also disappears at most depths (e.g B. mediterraneus; Morales-Nin et al. 1996) or is even replaced by a smaller-deeper trend (e.g. L. lepidion and C. labiatus; Stefanescu et al. 1992b).

When a comparison of our results with those obtained by Stefanescu et al. (1993) in the Balearic basin is made, similar trends in fish assemblages are evident. Nevertheless, some differences in the relative abundance and biomass of several species become apparent between the 2 areas (Fig. 6). In this way, the percentages obtained for the large-sized fish Alepocephalus rostratus, the most abundant species in the surveyed area, are higher than those reported in the Balearic basin, where this is a subdominant species. On the other hand, the small-sized species Lepidion lepidion, which is dominant and subdominant on the middle and lower slopes, respectively, off the Balearic basin, shows low values of relative abundance and bio- 

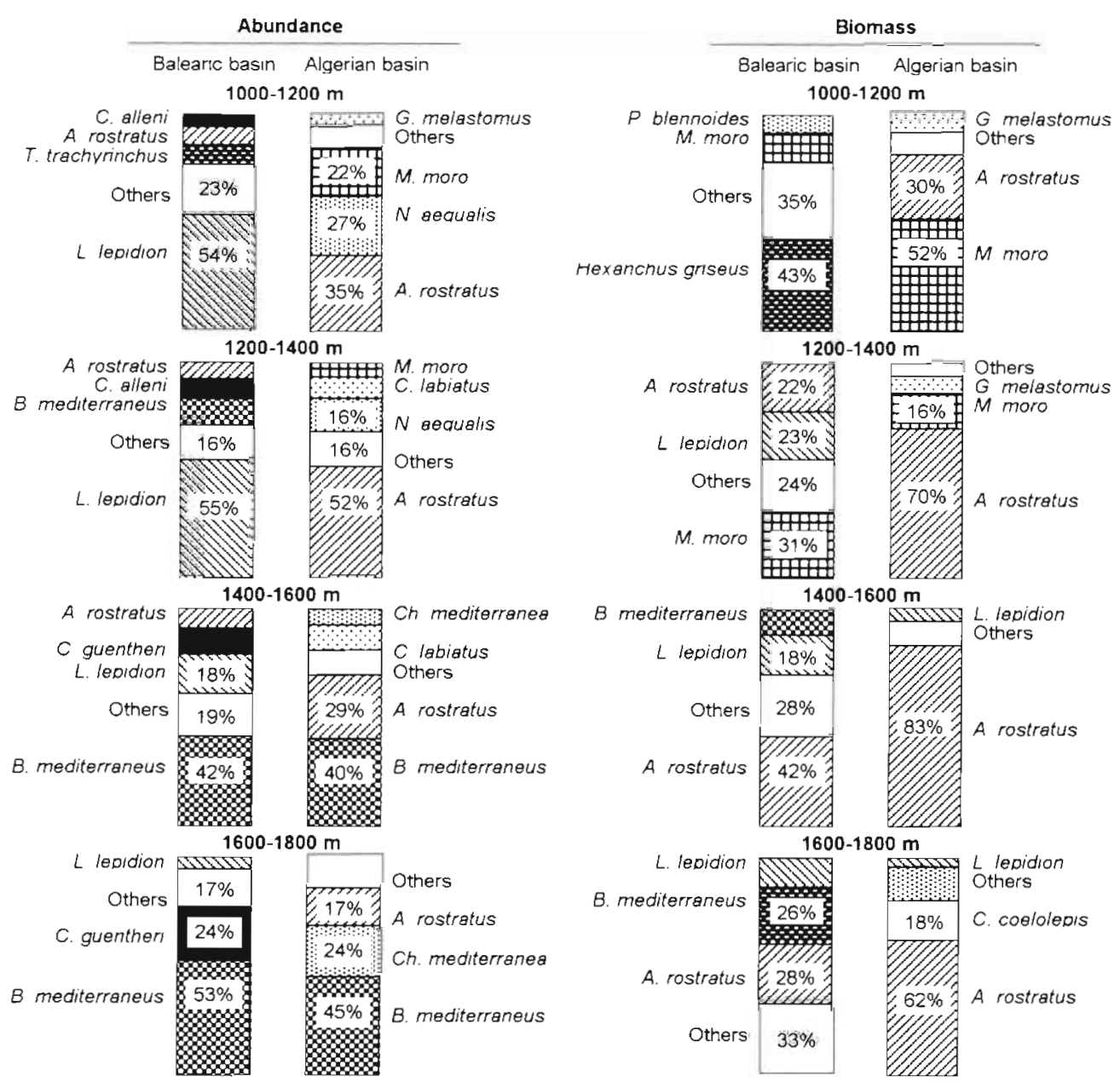

Fig. 6. Relative abundance and biomass by depth strata of the dominant and subdominant species in 2 areas of the western Mediterranean, north (Balearic basin) and south (Algerian basin) of the Balearic Islands (see Fig. 1). The results obtained in thus study have been adapted to the depth intervals selected by Stefanescu et al. (1993). Samples were obtained with 2 different semi-balloon otter trawls towed from a single warp: an OTMS-27.5 with an effective horizontal opening of $14 \mathrm{~m}$ (Sardà et al. 1994) in the Algerian basin and an OTSB-14 with an effective horizontal opening of $6.7 \mathrm{~m}$ (Sulak 1984) in the Balearic basin. For both gears vertical opening ranged from 1.5 to $2 \mathrm{~m}$ (Merrett \& Marshall 1981, Sulak 1984, Sardà et al. 1994). Full species names given in Table 1

mass off the southern Balearic Islands. The few specimens of the rare large species Hechanchus griseus (Bonnaterre, 1788) represents the $43 \%$ of the biomass in the Balearic basin and were trawled from submarine canyons, where food trophic availability is presumably greater (Stefanescu et al. 1993).

In the Algerian basin, the subdominant species in terms of abundance are the middle and large-sized fish Nezumia aequalis, Mora moro and Galeus melastomus. By contrast, in the Balearic basin, the subdominant species are the small-sized species Cataetyx alleni and Coryphaenoides guentheri, and the largesized fish Trachyrincus trachyrinchus, which was caught in very low numbers in the study area (Table 1). On the other hand, Bathypterois mediterraneus has similar relative abundances in both areas, but its pro- portion within the fish assemblages, in terms of biomass, seems to be higher in the Balearic basin than in the Algerian basin.

The differences observed between the 2 areas might be explained in relation to the distinct effectiveness of the 2 bottom trawls used, because the relative sampling capacities of different gears used in deep demersal fish studies vary between species (Merrett et al. 1991, Gordon \& Bergstad 1992). In this way, the high catches of larger species on the middle and lower slopes off the southern Balearic islands are most probably due in part to the use of the more efficient OTMS-27.5 gear with a horizontal opening twice that of the OTSB-14. To assess this effect, the abundance values of the main species caught with an OTMS-27.5 in the Balearic basin between 1100 and $1300 \mathrm{~m}$ (Stefanescu et al. 1994) were 
Table 4. Abundance (fishes per $1000 \mathrm{~m}^{2}$ ) of the main species caught in 2 areas of the western Mediterranean, the Balearic basin (Stefanescu et al 1994) and the Algerian basin (present study), between depths of 1000 and $1300 \mathrm{~m}$ obtained with the same gear, an OTMS-27.5 trawl

\begin{tabular}{|c|c|c|c|}
\hline & $\begin{array}{l}\text { Abun } \\
\text { Algerian basin } \\
(\mathrm{n}=11)\end{array}$ & $\begin{array}{l}\text { dance } \\
\text { Balearic basin } \\
\qquad(n=7)\end{array}$ & $t$-test \\
\hline Alepocephalus rostratus & $1.48 \pm 0.09$ & $2.14 \pm 0.30$ & $t_{11.58}=2.13 ; p>0.05$ \\
\hline Nezumia aequalis & $0.82 \pm 0.14$ & $0.07 \pm 0.01$ & $t_{1,11}=-5.13 ; \mathrm{p}<0.01$ \\
\hline Mora moro & $0.59 \pm 0.15$ & $0.25 \pm 0.06$ & $t_{16}=-2.41 ; p<0.05$ \\
\hline Galeus melastomus & $0.19 \pm 0.04$ & $0.02 \pm 0.01$ & $t_{645}=-4.34 ; \mathrm{p}<0.01$ \\
\hline Phycis blennoides & $0.02 \pm 0.02$ & 0.00 & \\
\hline Cataetyx alleni & $0.01 \pm 0.01$ & $0.06 \pm 0.01$ & $t_{\mathrm{ib}}=3.20 ; \mathrm{p}<0.01$ \\
\hline Trachyrinchus trachyrinchus & $5 \quad 0.00$ & $0.19 \pm 0.07$ & \\
\hline Caelorhynchus labiatus & $0.15 \pm 0.09$ & $0.13 \pm 0.02$ & $t_{6,69}=-0.27 ; p>0.05$ \\
\hline Lepidion Jepidion & $0.07 \pm 0.03$ & $0.88 \pm 0.08$ & $t_{1.325}=9.74 ; \mathrm{p}<0.01$ \\
\hline Bathypterois mediterraneus & $0.11 \pm 0.03$ & $0.85 \pm 0.16$ & $t_{10.69}=4.6 ; p<0.01$ \\
\hline
\end{tabular}

compared with the samples taken at the same depth interval with the same gear in our study area. Some significant differences, with the same trend described in Fig. 6, are observed (Table 4). Nezumia aequalis, Mora moro, Galeus melastomus and Phycis blennoides were more abundant in the Algerian basin, and Cataetyx alleni, Trachyrincus trachyrinchus, Lepidion lepidion and Bathypterois mediterraneus were more abundant in the Balearic basin. Nevertheless, in the case of Alepocephalus rostratus no significant differences between the 2 areas were found once the same sampling gear was used. Thus, the differences observed in the relative composition shown in Fig. 6 could be due not only to the different efficiency of the sampling gear but to other factors as well. In the Balearic basin samples were taken all year round, whereas in the Algerian basin samples were taken only in autumn. Thus, seasonal events such as spawning aggregation and annual cycles of abundance cannot be excluded as determinants of the differences found.

In summary, the deep-sea fish assemblages on the continental slope in the Algerian basin showed a general trend in biomass and abundance similar to those found in the Balearic basin, but some differences were evident for several species between the 2 areas. These differences are probably caused by an insignificant exchange of bathyal fish fauna between the 2 areas due to the existence of topographical and associated hydrographic barriers. Submarine canyons on the slope in the Balearic basin (Monaco et al. 1990) exert an important influence not only on the environment but also on the megafaunal populations (Reyss 1971, De Bovée et al. 1990). Finally, the fish assemblages found in both areas appear to have evolved in a relatively independent manner in relation to different ecological parameters.
Acknowledgements. This paper is a result of the European Project 'Developing deepwater fisheries: data for their assessment and for understanding their interaction with and impact on a fragile environment' (EU FAIR PROJECT CI 95-0655. European Commission DG-XIV, Fisheries). The authors thank P. Torres, A. Bozzano, Dr G. Rotllant, Dr J. E. Cartes, Dr J. B. Company and Dr. C. Ruiz-Altaba for their help during the sampling cruises, as well as the captain and crew of the RV 'García del Cid We are particularly grateful to Joan Vives and Joan Ribas, skippers of the FV 'Almuixó' (La Vila Joiosa) and 'Germans curt' (Eivissa), respectively, for their help during the sampling strategy, and to Dr F. Maynou for providing Fig. 1. We also thank the referees for suggestions and comments which have helped us to improve this paper

\section{LITERATURE CITED}

Allué C (1985) Composición y estructura de la comunidad de peces demersales frente a Barcelona (Años 1980-81). Thalassas 3(1):57-90

Anderson ME, Crabtree RE, Carter HJ, Sulak KJ, Richardson MD (1985) Distribution of demersal fishes of the Caribbean Sea found below $2000 \mathrm{~m}$. Bull Mar Sci 37:794-807

Bianchi G (1992) Study of the demersal assemblages of the continental shelf and upper slope off Congo and Gabon, based on the trawl surveys of the RV 'Dr Fridtjof Nansen'. Mar Ecol Prog Ser 35:9-23

Blondel J (1979) Biogéographie et écologie. Masson, Paris

Bouchet P. Taviani M (1992) The Mediterranean deep-sea fauna: pseudopopulations of Atlantic species? Deep-Sea Res 39(2): $169-184$

Canals M, Serra J, Riba O (1982) Toponímia de la Mar catalana-Balear (amb un glossari de termes genèrics). Boll Soc Hist Nat Balears 26:169-194

Carney RS, Haedrich RL, Rowe GT (1983) Zonation of the fauna in the deep-sea. In: Rowe GT (ed) Deep-sea biology. The sea, Vol 8. Wiley Interscience, New York, p 371-398

Cohen DM, Pawson DL (1977) Observations from the DSRV ALVIN on populations of benthic fishes and selected larger invertebrates in a near Deep Water Dumpsite-106. NOAA Dumpsite Evaluation Rep, 77-1(2):423-458

Daget J (1976) Ordination des profils ecologiques. Nat Monspel Ser Bot 26:109-128

De Boveé F, Guidi LD, Soyer J (1990) Quantitative distribution of deep-sea meiobenthos in the north-western Mediterranean (Gulf of Lions). Cont Shelf Res 10:1123-1145

EUROMODEL GROUP (1995) Progress from 1989 to 1992 in understanding the circulation of the Western Mediterranean Sea. Oceanol Acta 18(2):255-271

Font J, Salat J, Julià A (1988) Permanent features of the circulation in the Catalan Sea. Oceanol Acta 9:51-57

Fujita T, Inada T, Ishito Y (1995) Depth-gradient structure of demersal fish community on the continental shelf and upper slope off Senday Bay, Japan. Mar Ecol Prog Ser 118:13-23

Gil de Sola L (1994) Ictiofauna demersal de la plataforma continental del mar de Alboran (Mediterráneo suroccidental ibérico). Bol Inst Esp Oceanogr 10(1):63-79

Gordon JDM (1986) The fish populations of the Rockall 
Trough. Proc R Soc Edinb 88(B):191-204

Gordon JDM, Bergstad OA (1992) Species composition of demersal fish in the Rockall Trough, north eastern Atlantic, as determined by different trawls. J Mar Biol Assoc UK 72:213-230

Gordon JDM, Duncan JAR (1985) The ecology of the deepsea benthic and benthopelagic fish on the slopes of the Rockall Trough, Northeastern Atlantic. Prog Oceanogr 1.; $37-69$

Gordon JDM, Merrett NR, Haedrich RL (1995) Environmental and biological aspects of slope dwelling fishes of the north Atlantic. In: Hopper AG (ed) Deep water fisheries of the North Atlantic Oceanic Slope. Kluwer Academic Publisher, Dordrecht

Grassle JF, Sanders HL, Hessler RR, Rowe GT, McLellan T (1975) Pattern and zonation-a study of the bathyal megafauna using the research submersible Alvin. DeepSea Res 22:457-481

Haedrich RL, Krefft G (1978) Distribution of bottom fishes in the Denmark Strait and Irminger Sea. Deep-Sea Res 25. $705-720$

Haedrich RL, Merret NR (1988) Summary atlas of deep-living demersal fishes in the North Atlantic Basin. J Nat Hist 22:1325-1362

Haedrich RL, Merret NR (1990) Little evidence for faunal zonation or communities in deep sea demersal fish fauna. Prog Oceanogr 24:239-250

Haedrich RL, Rowe GT, Polloni PT. (1975) Zonation of faunal composition of epibenthic population on the continental slope south of New England. J Mar Res 33:191-212

Haedrich RL, Rowe GT, Polloni PT (1980) The megabenthic fauna in the deep-sea south of New England, USA. Mar Biol 57:165-179

Hecker B (1990) Variation in megafaunal assemblages on the continental margin south of New England. Deep-Sea Res $37.35-57$

Hopkins TS (1985) Physics of the sea. In: Margalef R (ed) Key environments: Western Mediterranean. New York, Pergamon Press, p 100-125

Hutchenson K (1970) A test for comparing diversities based on the Shannon formula. J Theor Biol 29:151-154

Kohn AJ, Riggs AC (1982) Sample size and dependence in measures of proportional similarity. Mar Ecol Prog Ser 9: $147-151$

Koslow JA (1993) Community structure in North Atlantic deep-sea fishes. Prog Oceanogr 31:321-338

Lhorenz SE, Wiesenburg DA, De Palma IP, Johnson KS, Gustafson DE (1988) Interrelationship among primary production, chlorophyll, and environmental conditions in frontal regions of the Western Mediterranean Sea. DeepSea Res 35(5):793-810

Macpherson E, Duarte CM (1994) Patterns in species richness, size, and latitudinal range of East Atlantic fishes. Ecography 17:242-248

Macpherson E, Roel BA (1987) Trophic relationships in the demersal fish community off Namibia. In: Payne AIL, Gulland JA, Brink KH (eds) The Benguela and comparable ecosystems. S Afr J Mar Sci 5:585-596

Mahaut ML, Geistdorfer P, Sibuet M (1990) Trophic strategies in carnivorous fishes: their significance in energy transfer in the deep-sea benthic ecosystem (Meriadzeck Terrace Bay of Biscayl. Prog Oceanogr 24:223-237

Marshall NB, Merrett NR (1977) The existence of benthopelagic fauna in the deep-sea. Deep-Sea Res 24(suppl): 483-497

Massutí E, Morales-Nin B, Lloris D (1996a) Bathymetric distribution and recruitment patterns of Phycis blennoides
(Pisces: Gadidae) from the slope of the northwestern Mediterranean. Sci Mar 60(4):481-488

Massutí E, Morales-Nin B. Stefanescu C (1995) Distribution and biology of five grenadier fish (Pisces: Macrouridae) from the upper and middle slope of the northwestern Mediterranean. Deep-Sea Res 3:307-330

Massutí E, Reñones O, Carbonell A, Oliver P (1996b) Demersal fish communities exploited on the continental shelf and slope off Majorca (Balearic Islands, NW Mediterranean). Vie Milieu 46(1):45-55

Matallanas J (1979) Contribución al estudio de la ictiofauna de la zona explotada por las barcas de pesca de Blanes (Mar Català). Boll Soc Hist Nat Balears 23:127-145

Mauchline J. Gordon JDM (1991) Oceanic pelagic prey of benthopelagic fish in the benthic boundary layer of a marginal oceanic region. Mar Ecol Prog Ser 74:109-115

Maurin CL (1962) Etude des fonds chalutables de la Méditerranée occidentale (écologie et pêche). Résultats des campagnes des navires océanographiques 'Président Theodore Tissier', 1957 à 1960, et 'Thalassa', 1969 et 1961. Róv Trav Inst Pèches Marit 26(2):163-218

Maurin CL (1965) Etude des fonds de Pêche des lles Baléares. Campagne de 'I'Ichthys', avril-mai 1965. Sci Pêche 139:1-9

Maurin CL (1968) Ecologie ichthyologique des fonds chalutables atlantiques (de la baie ibéroamericaine à la Mauritanie) et de la Méditerranée occidentale. Résultats des campagnes des navires océanographiques 'Président Theodore Tissier', 1957 à 1960, et 'Thalassa', 1969 et 1961. Rév Trav Inst Pêches Marit 32(1):1-147

Merrett NR (1987) A zone of faunal changes in assemblages of abyssal demersal fish in the eastern north Atlantic: a response to seasonality in production? Biol Oceanogr 9 : $185-244$

Merrett NR, Domanski PA (1985) Observations on the ecology of deep-sea bottom living fishes collected off northwest Africa: II. The Moroccan slope $\left(27^{\circ}-34^{\circ} \mathrm{N}\right)$, with special reference to Synaphobranchus kaupi. Biol Oceanogr 3(4) 349-399

Merrett NR, Gordon JDM, Stehmann M, Haedrich RL (1991) Deep demersal fish assemblages structure in the Porcupine Seabight (eastern North Atlantic): slope sampling by three different trawls compared. J Mar Biol Assoc UK 71:329-3.58

Merrett NR, Marshall NB (1981) Observations on the ecology of deep-sea bottom living fishes collected off northwest Africa $\left(08^{\circ}-27^{\circ} \mathrm{N}\right)$. Prog Oceanogr 9:185-244

Millot C (1985) Some features in the Algerian Current. J Geophys Res 90:7169-7176

Millot C (1987) Circulation in the Western Mediterranean Sea. Oceanol Acta 10(2): 1.43-149

Monaco A, Biscave $P$, Soyer $J$, Poklington $R$, Heussner $S$ (1990) Particle fluxes and ecosystems response on a continental margin: the 1985-1988 Mediterranean ECOMARGE experiment. Cont Shelf Res 10:809-839

Morales-Nin B, Massutí E, Stefanescu C (1996) Bathymetric distribution and growth patterns of Bathypterois mediterraneus from the north-western Mediterranean Sea. J Fish Biol 49(Suppl A):276-288

Pearcy WG, Stein DL. Carney RS (1982) The deep-sea benthic fish fauna of the northeastern Pacific Ocean on Cascadian and Tufts Abyssal plains adjoining continental slopes. Biol Oceanogr 1:375-428

Pielou EC (1969) An introduction to mathematical ecology Wiley, New York

Pinot J, Tintoré J, Gomis D (1995) Multivariate analysis of the surface circulation in the Balearic Sea. Prog Oceanogr $36: 343-376$ 
Reyss D (1971) Les canyons sous-marins de la mer Catalane, le rech du Cap et le rech Lacaze-Duthiers. III. Les peuplements de macrofaune benthique. Vie Milieu 22(3B):529-613

Sardà F, Cartes JE, Company JB (1994) Spatio-temporal variations in megabenthos abundance in three different habitats of the Catalan deep-sea (Western Mediterranean). Mar Biol 120:211-219

Sardà F, Cartes JE, Company JB, Albiol A (1998) A modified commercial truis used to sample deep-sea megabenthos. Fish Sci (in press)

Shannon CE, Weaver W (1949) The mathematical theory of communication. University of lllinois Press, Urbana

Smale MJ, Roel BA, Badenhorst A, Field JG (1993) Analysis of the demersal community of fish and cephalopods on the Agulhas Bank, South Africa. J Fish Biol 43(Suppl A): 169-191

Sneath PHA, Sokal RR (1973) Numerical taxonomy. Freeman, San Francisco

Stefanescu C, Lloris D, Rucabado J (1992a) Deep-living dem-

Editorial responsibility: Otto Kinne (Editor),

Oldendorf/Luhe, Germany ersal fishes in the Catalan Sea (western Mediterranean) below a depth of $1000 \mathrm{~m}$. J Nat Hist 26: 197-213

Stefanescu C, Lloris D, Rucabado J (1993) Deep-sea fish assemblages in the Catalan Sea (western Mediterranean) below a depth of $1000 \mathrm{~m}$. Deep-Sea Res 40:695-707

Stefanescu C, Morales-Nin B. Massutí E (1994) Fish assemblages in the Catalan Sea (western Mediterranean): influence of a submarine canyon. J Mar Biol Assor UK 74: $499-512$

Stefanescu C, Rucabado J, Lloris D (1992b) Deep-size trends in western Mediterranean demersal deep-sea fishes. Mar Ecol Prog Ser 81:205-213

Sulak KJ (1984) A comparatıve ecological analysis of temperate and tropical demersal deep-sea fish faunas in the western North Atlantic. PhD dissertation, Univ of Miami

Vinogradov ME, Tseitlin VB (1983) Deep-sea pelagic domain (aspects of bioenergetics). In: Rowe GT (ed) Deep-sea biology, The sea, Vol 8. Wiley Interscience, New York, p $123-165$

Submitted: December 16, 1997; Accepted: May 29, 1998 Proofs received from author(s): September 7,1998 